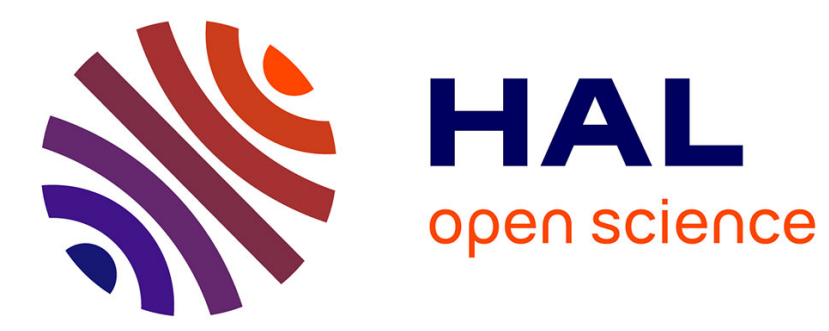

\title{
The spontaneous-autobenefactive prefix in Japhug Rgyalrong
}

Guillaume Jacques

\section{To cite this version:}

Guillaume Jacques. The spontaneous-autobenefactive prefix in Japhug Rgyalrong. Linguistics of the Tibeto-Burman Area, 2015, 38 (2), pp.271-291. 10.1075/ltba.38.2.08jac . halshs-01287471

\section{HAL Id: halshs-01287471 \\ https://shs.hal.science/halshs-01287471}

Submitted on 13 Mar 2016

HAL is a multi-disciplinary open access archive for the deposit and dissemination of scientific research documents, whether they are published or not. The documents may come from teaching and research institutions in France or abroad, or from public or private research centers.
L'archive ouverte pluridisciplinaire $\mathbf{H A L}$, est destinée au dépôt et à la diffusion de documents scientifiques de niveau recherche, publiés ou non, émanant des établissements d'enseignement et de recherche français ou étrangers, des laboratoires publics ou privés. 


\title{
The spontaneous-autobenefactive prefix in Japhug Rgyalrong*
}

\author{
Guillaume Jacques
}

March 13, 2016

\begin{abstract}
This paper documents the morphosyntactic and semantic properties of the autobenefactive-spontaneous prefix nu-. It describes the regular and irregular morphological and morphophonological alternations displayed by this prefix, as well as its three main semantic functions, namely spontaneous, autobenefactive and permansive. Finally, it discusses the historical relationship of the autobenefactive prefix with other derivations, in particular the vertitive nu- and the anticausative prenasalization.

Keywords: Middle, Spontaneous, Anticausative, Autobenefactive, Japhug, Rgyalrongic, Kiranti
\end{abstract}

\section{Introduction}

There is a well-attested cross-linguistic tendency for the same marker to be used for reflexive or passive and for the expression of spontaneous events without a volitional agent or anticausative (Kemmer 1993: 142-144). This closeness is best exemplified by middle constructions using a reflexive marker

\footnotetext{
${ }^{*}$ Glosses follow the Leipzig glossing rules. Other abbreviations used here include: AUTO spontaneous-autobenefactive, CISLOC cislocative, CP complex predicate, EGOPH egophoric present, FACT factual/assumptive, GENR generic, IFR inferential evidential, HORT hortative, INV inverse, LNK linker, SENS sensory evidential, SFP sentence final particle, TRANSLOC translocative, VERT vertitive (motion back to the origin). The TAM markers for imperfective and perfective are based on orientational prefixes; motion and concrete action verbs can be used with any of the seven possible orientational prefixes. Other verbs have a lexicalized direction (see Jacques 2014a: 266-270). Words of Chinese origin that are not fully integrated phonologically are indicated between chevrons $<>$. This work benefited from useful comments by Giorgio Arcodia, Nathan W. Hill, Ken Mason, Alexis Michaud, Marc Miyake, Dmitry Nikolaev, Pavel Ozerov, Haeree Park, Vladimir Plungian, Roland Pooth, Marijn van Putten, Graham Thurgood, Fernando Zúñiga and one anonymous LTBA reviewer. The examples are taken from a corpus that is progressively being made available on the Pangloss archive (Michailovsky et al. 2014). This research was funded by the HimalCo project (ANR-12-CORP-0006) and is related to the research strand LR-4.11 "Automatic Paradigm Generation and Language Description" of the Labex EFL (funded by the ANR/CGI).
} 
in Romance and Slavic languages and also in various language families. ${ }^{1}$ In Sino-Tibetan, the suffix - cu in Dulong/Rawang (LaPolla \& Yang 2005) and the suffix $-s i$ in Kiranti languages are also example of quasi-prototypical middle markers (see Michailovsky 1988: 144-146, van Driem 1993: 125-129, Opgenort 2004: 260-263 and Bickel et al. 2010: 398).

Japhug presents a marker nu- that can be used in situations referring to spontaneous events or autobenefactive actions. ${ }^{2}$ This marker differs from the reflexive as observed in Romance, Slavic and Kiranti in several important ways.

First, Japhug also has a reflexive prefix (see for instance Jacques 2010b concerning Japhug Rgyalrong) as well as distinct passive, anticausative and antipassive prefixes (Jacques 2012c) and a reciprocal construction all formally and functionally distinct from the autobenefactive. Second, although Japhug nu-semantically belongs to the middle domain as defined by Kemmer (1993: 15), this marker can be applied to both intransitive and transitive verbs, and does not modify the valency of the verb. Third, in addition to marking autobenefactive and spontaneous actions, it also has a permansive ${ }^{3}$ aspectual value.

This paper is a description of the spontaneous-autobenefactive nu- in Japhug, and a contribution to the typology of middle marking systems. It comprises six sections. First, I present the morphological marking of transitivity in Japhug, and show that the spontaneous-autobenefactive marker has no influence on it. Second, I discuss the position of this prefix in the Japhug verbal template. Then, I describe the three main functions of this prefix: the expression of autobenefactive and grooming activities, spontaneous events and permansive aspect. Finally, I propose a series of hypotheses concerning the diachronic relationship of this prefix to other derivations in Japhug and other Rgyalrongic languages.

\section{Morphological transitivity}

Japhug verbs have two conjugations, transitive and intransitive. ${ }^{4}$ The intransitive conjugation indexes the person and number (singular, dual, plural) of the $\mathrm{S}$, while the transitive conjugation indexes the person and number

\footnotetext{
${ }^{1}$ The use of the term 'middle' in Kemmer (1993) and subsequent typological work differs from the morphologically-based definition of the middle in Indo-European linguistics. In this paper, I use 'middle domain' to refer to all constructions and derivations (such as passive, anticausative, reciprocal, autobenefactive etc) that can overlap with reflexive marking in particular languages.

${ }^{2} \mathrm{~A}$ similar marker exists in all core Rgyalrong languages, for instance nə- in Tshobdun (glossed as 'spontaneous' in Sun 2014: 634) and also in Khroskyabs (Lai 2013: 157-160).

${ }^{3}$ The term permansive or remansive refers to an aspect expressing the continuation of a process that has already started (François 2003: 130).

${ }^{4} \mathrm{~A}$ small class of labile verbs can be conjugated either transitively or intransitively (Jacques 2012c). All examples exhibit agent-preserving (i.e. $\mathrm{A}=\mathrm{S}$ ) lability.
} 
of both A and P. The indexation of arguments on transitive verbs follows a quasi-canonical direct-inverse system (see DeLancey 1981, Sun \& Shidanluo 2002, Jacques 2010a, Jacques \& Antonov 2014, Gong 2014). The person marking prefixes and suffixes of the intransitive conjugation can be combined with either direct marking (via stem alternation), inverse marking (the $w$ - prefix) or portmanteau prefixes (the local scenario markers $k u-$ $2 \rightarrow 1$ and ta- $1 \rightarrow 2$ ).

Transitive verbs can be unambiguously distinguished from intransitive ones by three morphological criteria. First, stem alternation in the non-past $1 / 2 / 3 \mathrm{SG} \rightarrow 3$ direct forms (including factual, imperfective, sensory, present, imperative and irrealis, see also Sun 2000, 2007). Second, presence of a past transitive prefix $-t$ - in the past $1 / 2 \mathrm{SG} \rightarrow 3$ forms. Third, in perfective $3 \rightarrow 3$ ' direct forms (without the inverse $w \gamma$ - prefix), a prefix $a$-appears between the verb stem and the orientation prefixes (and phonologically merges with them).

The morphological transitivity as indexed in verb morphology is strictly correlated with ergative marking on the A argument of a transitive verb (example 2), while $\mathrm{S}$ and $\mathrm{P}$ arguments are unmarked (examples 1 and 2). The ergative clitic ku is obligatory with noun phrases and third person pronouns, but in the case of first and second person pronouns it is optional.

(1) rғrlpu пи ти-рjя-гъzit king DEM NEG-EVD.IPFV-be.there

The king was not there. (Nyima wodzer2003.1, 18)

(2) rғrlpu nu $k u$ li $\quad c i \quad$ uा-rzaß ku- $\beta$ ry king DEM ERG again INDEF 3SG.POSS-wife NMLZ:S/A-be.new ci $\quad$ pr-car.

INDEF IFR-look.for

The king married a new wife. (140504 baixuegongzhu, 15)

Verbal morphology, combined with ergative marking, can be used to test whether a particular derivation modifies verb transitivity or not. For instance, examples 3 and 4 show that while transitive verbs with third person arguments take the perfective $3 \rightarrow 3$ ' direct $a$ - prefix, corresponding verbs with the antipassive $r \gamma$-do not. Moreover, in example 3 the argument corresponding to the person learning would take the ergative with the base verb $\beta z j o z$ if an overt A were inserted, but does not with the antipassive verb $r \gamma$ - $\beta z j o z$. Likewise, other voice derivations such as the passive $a-/ \gamma-$, the anticausative, the reciprocal $(a-/ \gamma$ - combined with reduplication) and the reflexive $\bar{z} \gamma \boldsymbol{\gamma}$-are incompatible with transitivity markers such as the perfective $3 \rightarrow 3$ ' direct $a$ - prefix, the past $1 / 2 \mathrm{SG} \rightarrow 3$ suffix $-t$, stem III alternation, and with ergative case marking. 
(3) <qiche $>k \gamma-\gamma \gamma-\beta d i \quad$ pur-a- $\beta z j o z$

car INF-CAUs-be.good PFV-3 $\rightarrow 3$ '-learn

He learned (how to) fix cars. (14 tApi taRi, 191)

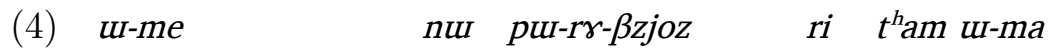

3SG.POSS-daughter DEM PFV-A.PASS-learn but now 3SG.POSS-work

me

not.exist:FACT

Although her daughter went to school, now she does not have any (real) job. (17 lhazgron, 58)

On the other hand, the presence of the autobenefactive/spontaneous prefix, unlike other derivations belonging to the middle domain, has no influence on morphological or syntactic transitivity.

Examples 5 and 6 show that the prefix nu-does not affect stem alternation. In these two examples, stem III $-n d r m$ is found instead of stem I $-n d o$, as is expected for a verb that is in the imperative with a $2 \mathrm{SG} \mathrm{A}$ and a third person $\mathrm{P}$, even in 5 with the autobenefactive/spontaneous.

(5) laвjury пrъo tr-nu-ndrm je tce, ąo jryrt ci

staff 2SG IMP-AUTO-take[III] HORT LNK 1SG toilet INDEF

lu-ce-a

IPFV:UPSTREAM-go-1SG

Take the staff (to hit the animal), I am going to the toilet. (The tiger, 13)

(6) ki tr-ndrm tce, konla zо u-pu

this IMP-take[III] LNK really EMPH 3sG.POSS-CP:keep

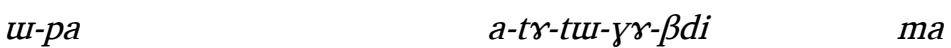

3SG.POSS-BARE.INF:CP:keep IRR-PFV-2-CAUS-be.well LNK

Take this, you will have to keep it well because... (140428 mu e guniang, 24)

Example 7 shows that ergative case marking on the A is not lost when the verb has the autobenefactive / spontaneous prefix, and comparing 7 with 8 reveals that the perfective direct $3 \rightarrow 3^{\prime}$ prefix $a^{5}$ is found even in cases when the autobenefactive $n u-$ is present. The verb has stem I -ndo in these two examples as stem III is restricted to non-past tenses, and is not compatible with the perfective.

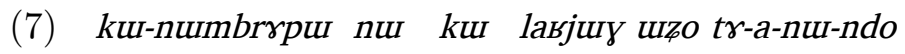
NMLZ:S/A-ride DEM ERG staff 3 SG PFV-3 $\rightarrow 3$ '-AUTO-take[I] лиu-пu.

SENS-be

\footnotetext{
${ }^{5}$ The prefix $a$ - is restricted to transitive non-local scenarios without inverse marking.
} 
The rider took the staff (for himself). (The tiger, 14)

(8) qas ku-fse tsuku tr-a-ndo

hoe NMLZ:S/A-be.like several PFV-3 $\rightarrow 3$ '-take[I]

He took a hoe (and other tools). (The fox, 79)

Finally, examples 9 and 10 show that the transitive past suffix $-t$ appears both in verb forms with and without the autobenefactive-spontaneous prefix nut-. ${ }^{6}$

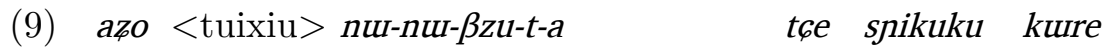

1SG retire PFV-AUTO-do-PST:TR-1SG LNK everyday here

ku-nu-rrzi-a

EGOPH-AUTO-stay-1SG

I retired, and (now) stay (at home) here everyday. (Conversation 2013)

(10)

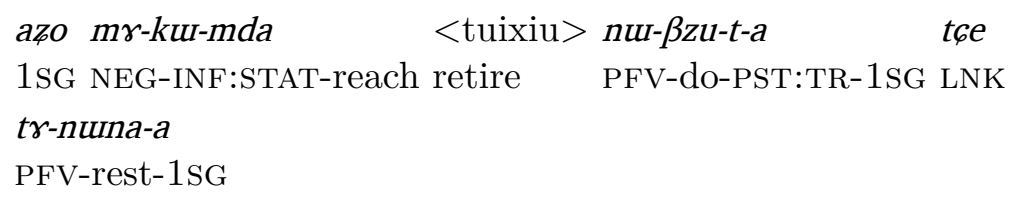

I retired early (before the time was reached). (17 Lhazgron, 73)

The examples above prove that transitive verb forms with the autobenefactive / spontaneous present all the morphological properties of transitive verbs: the prefix nu- has no influence on verb transitivity. In this regard, Japhug nu- is closer to the classical Indo-European morphologically-marked middle (see for instance Pooth 2014: 19) than most constructions labelled 'middle' in the typological literature, especially Romance and Slavic.

\section{Position in the template}

The Japhug verbal template follows the general structure in Table 1 (see Jacques 2012d and Jacques 2013c).

The autobenefactive / spontaneous prefix is peculiar in that it can occupy two distinct slots depending on the verb form: it can occur in slot 12, after the passive or denominal prefix $a_{-}$, but in the case of verbs without prefix $a-$, it occurs to the left of the reflexive prefix, as in example 11.

\footnotetext{
${ }^{6}$ Note that the homophony between the autobenefactive-spontaneous prefix and the perfective 'towards west' prefix nu- is fortuitous. The latter only appears verbs that lexically select this particular orientation prefix, or verbs of motion when the orientation 'towards west' is appropriate. In 9 and 10, we know that the nu- in nu- $\beta z u-t-a$ PFV-doPST:TR-1SG must be perfective and not autobenefactive because the transitive past suffix $-t$ - cannot occur in a verb form without a perfective orientation prefix.
} 
When people we cherish come, or when we (wish) to treat ourselves, (30 macha, 74)

The prefix nu- occurs in slot 12 for all verbs whose stem begins in a-, even when $a-$ is neither the passive or the denominal at least synchronically. For instance, in verbs such as aryi 'be blue', whose stem is disyllabic (the aelement is not a prefix), the spontaneous prefix is infixed after the $a-$, as in example 12 (see also 25 below).

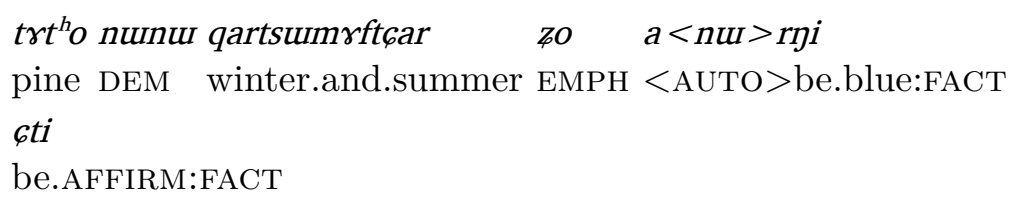

The pine (remains) green the whole year. (07 tAtho, 51)

There is one exception to this rule. The verb atur 'meet, run into' (conjugated intransitively) has two different autobenefactive forms (also intransitive), a regular one $a<$ nu $>$ tur 'meet by oneself' (as in 13), and nu-rtury 'run into (by mistake), happen to be in' (14).

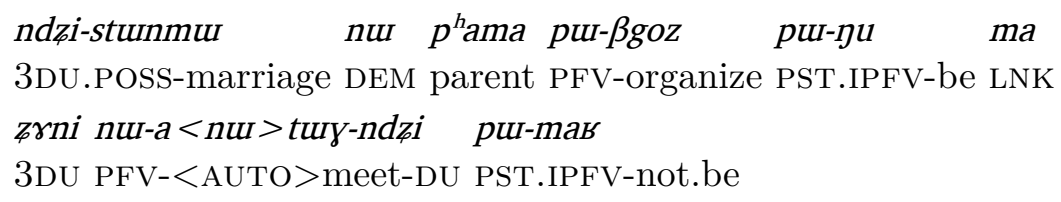

Their marriage was arranged by their parents, they did not get together by themselves. (elicited)

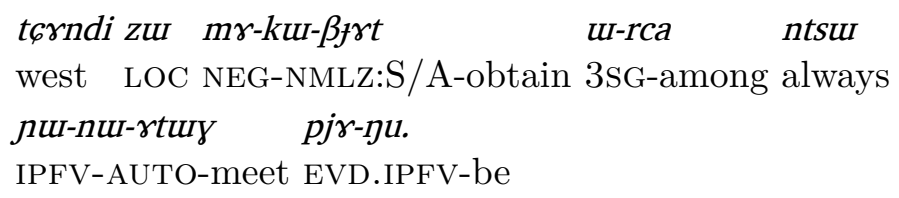

On the other side, he always happened to be among those who did not get anything (of the food being distributed). (28 qAjdoskAt,138)

The verb nu-rtur 'run into (by mistake)' has the autobenefactive prefix nu- in the same slot as the homophonous applicative nu- (see Jacques 2013a). Its meaning is not completely predictable from the base verb.

Another example of irregularity related to verbs in $a-$, is the verb antsrndu 'to be exchanged by mistake' (intransitive), which derives from srndu 'exchange' (transitive) by a combination of the passive $a-$ and an allomorph $n t-$ of the autobenefactive/spontaneous nut-. This verb is anomalous 
in two regards. First, there is no corresponding simple passive verb *asrndu 'be exchanged' : srndu 'exchange' is morphologically the causative of andu 'be exchanged' (mainly used about money). Second, the allomorph $n t-$ is not found in any other verb; the $-t$ - is epenthetic here, since the cluster $-n s-$ is not attested in Japhug.

Examples like nut-rtur 'run into (by mistake)' and antsrndu 'to be exchanged by mistake' suggest the autobenefactive/spontaneous nu-, despite its high productivity, is better treated as a derivational rather than an inflectional morpheme, since (i) the meaning of the derived verb is not always predictable and (ii) there is not always, at least synchronically, a corresponding base verb whose only difference with the derived verb is the absence of an autobenefactive/spontaneous prefix.

Verbs in $a-$ are not the only ones where the prefix nu- is infixed. The irregular existential verbs grzu 'be there, exist (sensory)' and mane 'not exist (sensory)' also take the spontaneous marker as an infix rather than as a prefix as in 15; note that all prefixes, including the second person tul-and the generic $k u-$ are infixed in the conjugation of these verbs (see Jacques 2012a, under review).

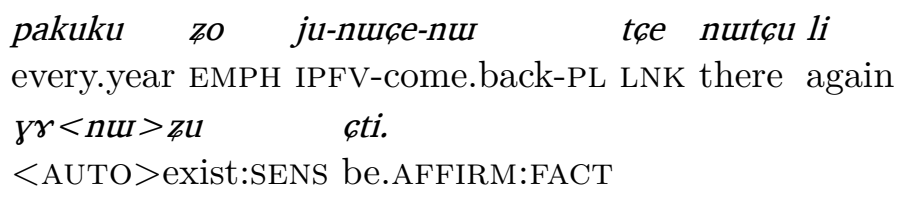

They come back every year, and it is still there. (20 grWBgrWB, 51)

Finally, an interesting property of the autobenefactive-spontaneous is that, like the inverse prefix (Jacques 2013c: 199), it is obligatorily infixed within the progressive asu-, as in example 16.

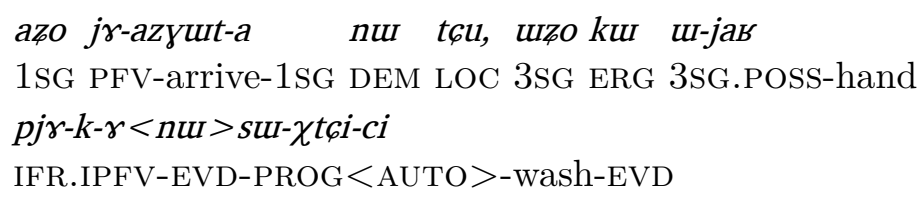

When I arrived (there), he was washing his hands. (elicitation, Chen Zhen) 


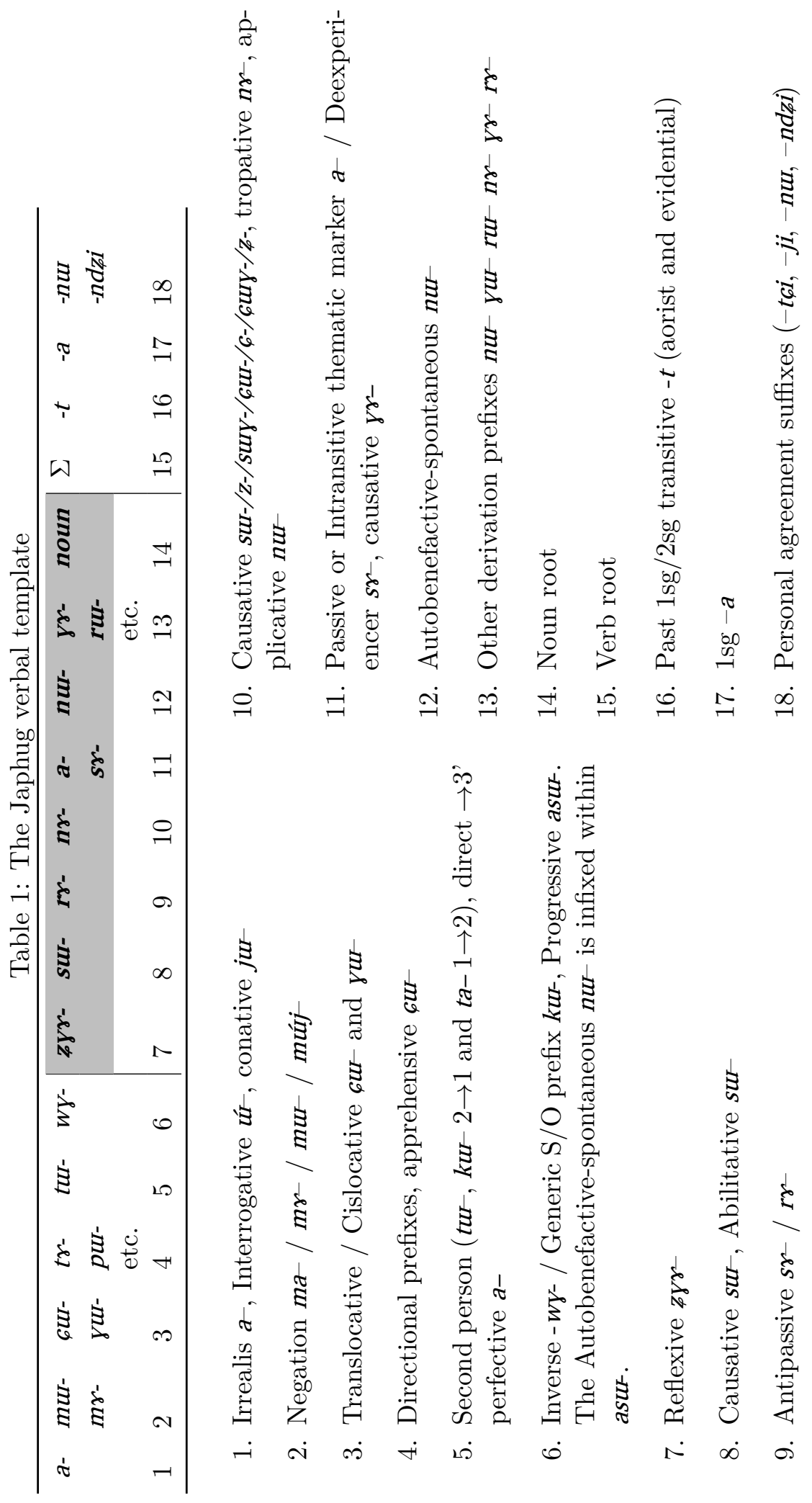


In addition to the issue of position in the template, the autobenefactive nu- presents two noteworthy regular morphophonological alternations. First, it can be realized as $n$ - before all prefixes with the shape $n u-$ or $n \boldsymbol{r}$ (denominal, applicative or tropative), as in example 17.

(17) tš пu tcu pjr-n-пшzщß.

road DEM LOC IFR-AUTO-sleep

He slept on the road. (140505 liuhaohan zoubian tianxia, 120)

Second, it can be optionally realized with emphatic gemination, especially in its use in the protasis of concessive conditionals (see 25 and 26 below).

\section{Autobenefactive}

The prefix nu- is commonly used with transitive verbs when the $\mathrm{P}$ bears a possessive prefix coreferent with the A, especially in the case of body parts and other inalienably possessed nouns, as in examples $18^{7}$ and 19 . It expresses that the $\mathrm{A}$ is affected by its own action.

(18) $n r-k u$

puI-nu- $\chi$ tढi

2SG.POSS-head IMP-AUTO-wash

Wash your head.

(19) шъо ku иш-sroь

ko-nu-ri

лиu-pu

3SG ERG 3SG.POSS-life IFR-AUTO-save SENS-be

He saved his own life. (140512 yufu yu mogui, 127)

The autobenefactive nu-can also refer to an action done for the benefit of a particular referent, which can be any of the core arguments. ${ }^{8}$ In these cases a pronoun coreferent with the referent can be placed just before the verb. This pronoun cannot bear the ergative marker even when it refers to the $\mathrm{A}$, as ${ }_{6} \mathrm{rni}$ 3DU in example 20. It can also be the distributive pronoun zaka 'each one' as in 21.

$$
\begin{aligned}
& n \gamma-p i \quad \text { ni } k u \text {.. qajyi nura } \\
& \text { 2SG.POSS-elder.sister DU ERG ... bread DEM:PL } \\
& \text { ku-mum zrni tu-nu-ndza-ndzi, ü-rku } \\
& \text { NMLZ:STATIVE-tasty they.DU IPFV-AUTO-eat-DU 3SG.POSS-side }
\end{aligned}
$$

\footnotetext{
${ }^{7}$ This sentence would however still be grammatical without the nu-prefix.

${ }^{8}$ For benefactive towards non-core arguments, two constructions are available in Japhug, either marking the beneficiary with the genitive zu or as a possessive prefix with the noun ndza 'reason' (for instance $n \boldsymbol{r}$-ndza 2SG.POSS-reason 'for your sake'). These two strategies are attested in many other languages of the world (see Zúñiga \& Kittilä 2010: $7-10)$.
} 


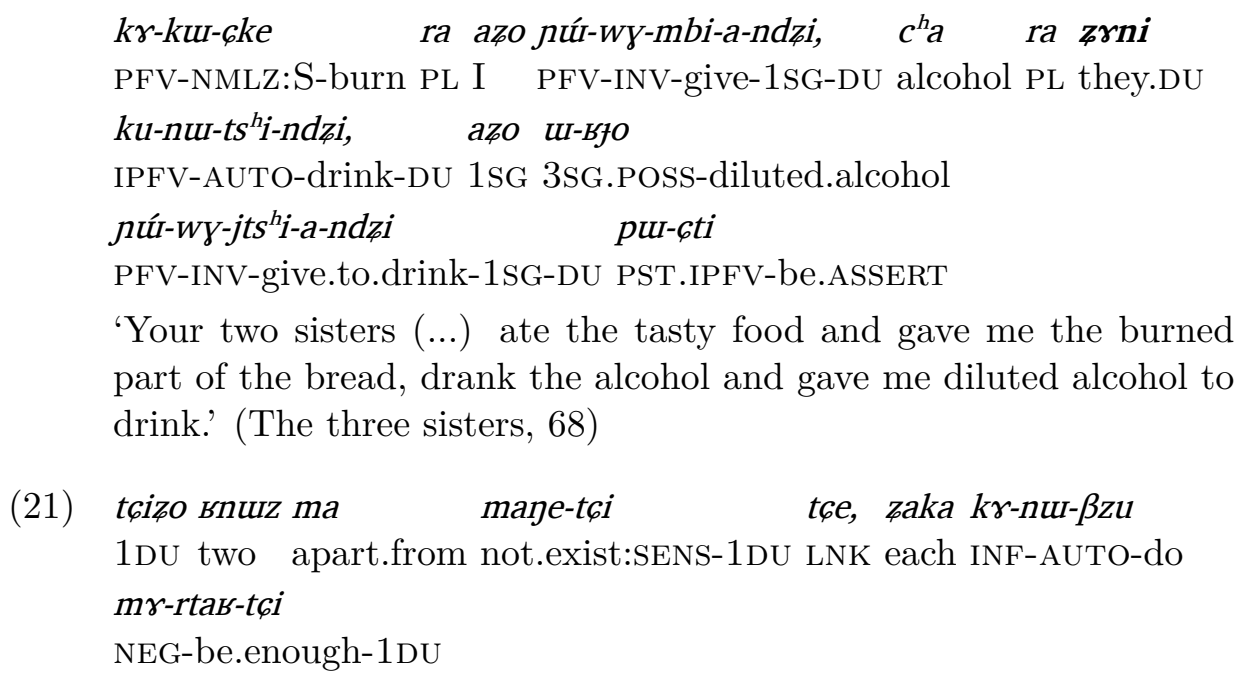

We are only two, we are not enough people to act separately. (The three sisters, 74)

The autobenefactive value of the prefix nu- in the imperative is used to convey a softened tone, expressing mild suggestion rather than order (examples 22 and 23). Note that the prefix nu- can have a different semantics in the imperative, namely 'do $\mathrm{X}$ as much as you want (the result will be the same)' (see 28 above).

(22) пrъо пипи tсu krndza ku-тum

2SG DEM LOC food NMLZ:S/A-be.tasty

6-tr-nu-ndze

TRANSLOC-IMP-AUTO-eat[III]

Go and eat nice food there! (140426 jiagou he lang, 64)

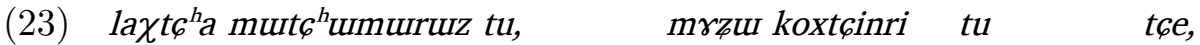
things all.kind exist:FACT also silk.thread exist:FACT LNK

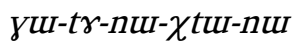
CISLOC-IMP-AUTO-buy-PL

There are all kinds of things, there are silk threads, come and buy them! (140504 baixue gongzhu, 121-122)

\section{Spontaneous}

The prefix nu- marks spontaneous actions occurring without any external cause or against of the will of a particular referrent.

In the case of animals, plants and inanimate beings, nu-can be used to express their apparent spontaneous growth, as in 24 . 
(24) tce zrury nut tce, tsuku ku tu-prchas u-ggu LNK louse DEM LNK some ERG INDEF.POSS-navel 3SG-inside tu-nuIPFV-AUTO-come.out be:FACT IPFV-say-PL be:FACT LNK mrxsi та шъо лит-ku-nu- $\beta z e \quad c i$ NEG:GENR:A:know LNK 3SG IPFV-NMLZ:S/A-AUTO-grow INDEF nut-Gti t6e, SENS-be.AFFIRM LNK

The louse, some say that it comes from the navel, I don't know, it grows by itself. (21 mdzadi, 54-55)

This spontaneous value of the prefix nu- explains its frequent presence in the protasis of alternative (25) and scalar (26) concessive conditionals (see Jacques 2014a): in these constructions, the result described in the apodosis takes place regardless of whether the condition in the protasis is fulfilled or not. The prefix nu- expresses the fact that the resulting action is independent of the condition.

(25) the tul-sum pu-a $<$ nnum $>r i$ nr ju-ku-ce, LNK INDEF.POSS-mind PFV-<AUTO>go[II] LNK IPFV-GENR:S/P-go

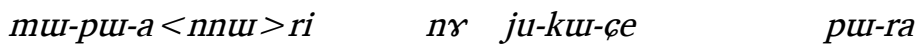
NEG-PFV- <AUTO > go[II] LNK IPFV-GENR:S/P-go PST.IPFV-have.to Whether one liked it or not, one had to go. (14 tApi taRi, 212)

(26) пu li ü-qa лu- $\beta z e$ лuDEM again 3SG.POSS-foot IPFV-grow SENS-be:AFFIRM LNK uा-типтов pu-nnu-tu kunr, uा-ryi ra 3SG.POSS-flower PST.IPFV-AUTO-exist also 3SG.POSS-seed PL $k \gamma$-mto maje. INF-see not.exist:SENS

This one also grows by its root, as even if it has flowers, (I) have never seen its seeds. (17 ndZWnW, 155)

An extension of the spontaneous value of the prefix num- is the meaning 'casually', 'at one's will', 'whatever' (Chinese 随便 suíbiàn), as in 27.

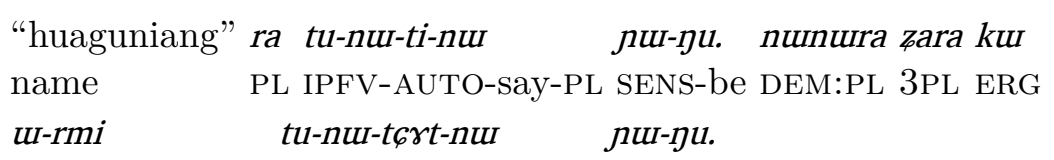

They say 'huaguniang', they call them like that. (implied meaning: they invented their name, it is not a real name; 28 qapar, 235)

In the imperative, the spontaneous can be used to mock the addressee, telling him that all his actions will be in vain, as in 28 . Note however that 
the prefix nu- can also express a mild imperative, as in examples 22 and 23 below, depending on the context.

(28) пrъо пи-пu-уrwu ma, nr-ku-nur-mu

2SG IMP-AUTO-cry LNK 2SG.POSS-NMLZ:S/A-APPL-be.afraid

me ma mr-ta-mbi

not.exist:FACT LNK NEG-1 $\rightarrow$-give:FACT

You can cry as much as you like, nobody is afraid of you, I won't give (my daughter) to you (in marriage).(The frog1, 149)

With a human S/A, nu- can indicate a action performed of one's own volition, without being forced by anything or anyone, as in 29 , or without help from anybody else ('by oneself'), as in 30 .

ąo pju-kut-yrrat-a-nut mr-ra ma azo

1SG IPFV:DOWN-2 $\rightarrow 1$-throw-1SG-PL NEG-FACT:need because 1SG

pjul-nu-mtsas-a

jry

NEG-IPFV:DOWN-AUTO-jump-1SG FACT:be.possible

You don't need to throw me in there, I will jump of my own free will.

(30) ақо қо z-лиu-nut-ru-a jul-nts ${ }^{h_{i}}$

1SG EMPH TRANSLOC-IPFV-AUTO-look-1SG SENS-have.to

I have to go to have a look by myself. (140507 tangguowu, 139)

Somewhat paradoxically, nu- can also indicate that an action occurs by mistake or against the volition of the S/A, as in 31 .

(31) us-qom ci pu-a-nu-glury

3SG.POSS-tear INDEF PFV-3 $\rightarrow 3$ '-AUTO-drop SENS-be

She shed a tear (involuntarily). (Kunbzang 228)

The verb jmut 'forget' almost always appears with nu- in the corpus (in 23 examples out of 28). In the first person, the autobenefactive / spontaneous can be combined with the inferential to insist on the non-volitionality of the action, as in 32 .

(32) $\quad m r-x s i$

ko, nura jr-nu-jmut-a

NEG-GENR:know SFP DEM:PL IFR-AUTO-forget-1PL

I don't know, I forgot those things. (Conversation)

It could seem to be contradictory that a single marker has such opposite semantic values. However, in both cases the action takes place against or independently of the will of a particular referent or regardless of the completion of another action. This referent can be an argument of the sentence, as in examples 31 and 32 , or can be an external referent, without syntactic function in the sentence, as in 29. 


\section{Permansive}

In addition to the two previous meanings, which are relatively straightforward for a middle marker, the spontaneous-autobenefactive prefix is also used with an aspectual function. It expresses the continuity of an action or a state, despite the occurrence of another action which could have been expected to stop it (as in examples 33,34), or despite the fact that a long time has passed (see 12 above) like the adverb 'still' in English.

It can be used to insist on the fact that a particular state is maintained without change, as in 35 .

The permansive reading of the prefix nu- is only possible in nonperfective verb forms, in particular factual, imperfective, past imperfective evidential and sensory.

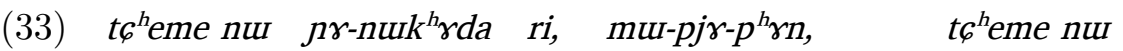
girl DEM IFR-convince LNK NEG-IFR-be.efficient girl DEM pjr-nut-grwu $\quad$ ti, EVD.IPFV-AUTO-cry be.AFFIRM:FACT

She (tried to) comfort the girl, but it was for nothing, the girl was still crying. (Bean and linen, 48)

(34) пuпu pjü-пgra

Gügur tce t6e лur-rom

DEM IPFV-ANTICAUS:make.fall before LNK LNK IPFV-be.dry

cti t6e, u-ryi nunu t6u

be:AFFIRM:FACT LNK 3SG.POSS-seed DEM LOC

a-nu-mp $p^{h}$ ur $\quad$ tit

PASS-AUTO-wrap:FACT be:AFFIRM:FACT

Before (the flower) falls down, it dries up, and its seed is still wrapped in it. (13 tCamu, 59)

(35) zmbulum chondrre grüßgrü $\beta$ ku-fse

type.of.mushroom COMIT Matsutake NMLz:S/A-be.like

tr-ধов tсе хрІовхрlов ku-ра tсе

PFV-come.out LNK IDPH:II:spherical NMLZ:S/A-auxiliary LNK

zuruzrri nu-ku-nrwrt nu

progressively IPFV-NMLZ:S/A-open.towards.the.exterior DEM

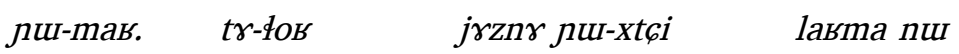

SENS-not.be PFV-come.out from SENS-be.small only DEM

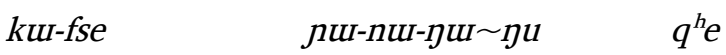

NMLZ:S/A-be.like SENS-AUTO-EMPH be LNK

It is not like the zmburlum and the Matsutake, which are spherical when they come out and progressively open towards the exterior. It is just that it is small when it comes out, (otherwise) it is already like that. (24 zwArqhAjmAG, 19) 
The permansive use of nu- is not without typological parallels. One of the clearest cases is the Russian pronominal element себе, originally the dative form of себя 'oneself', and which alongside its autobenefactive value, is used in certain contexts with a permansive value ('continue to ...'), generally with repetition of the verb as in example 36 taken from a song. ${ }^{9}$

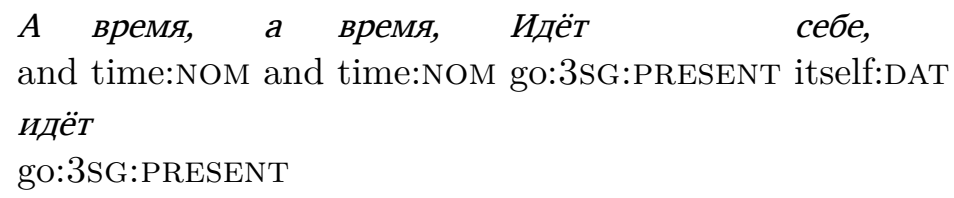

The time goes on and on...

This construction is not fully grammaticalized in Russian, but it is nevertheless a good parallel to the permansive value of nu- in Japhug. Since it is clear in Russian that the original meaning of this marker can only have been autobenefactive, not permansive or spontaneous, this fact suggests that the directionality of grammaticalization is more likely to be from autobenefactive to permansive in Japhug too. The following pathway in four stages can be proposed to account for this evolution; note that all four stages represent attested uses of Japhug nu-.

1. Do X for oneself (autobenefactive).

2. Do X on one's own.

3. Do X on one's own, disregarding external conditions.

4. Continue to do X, despite (adverse) external factors. (PERmansive)

At the present moment, we have no evidence that cognates of Japhug nu- in other Rgyalrongic languages have developed a permansive value, but further research might reveal similar examples elsewhere.

\section{Autobenefactive and other derivations}

The spontaneous-autobenefactive nu- in Japhug has cognates in other Rgyalrongic languages, in particular in Khroskyabs (its cognate $N$ - is discussed in Lai 2013: 157-160). Since this prefix presents irregularities in Japhug and complex morphophonological alternations in Khroskyabs, and since no obvious lexical source can be proposed as its lexifier in either language, it is reasonable to hypothesize that it can be reconstructed to protoRgyalrongic with at least the spontaneous and autobenefactive functions (the permansive function has not been documented elsewhere).

\footnotetext{
${ }^{9}$ I would like to thank Dmitry Nikolayev and Pavel Ozerov for pointing out this fact to me, providing examples and suggesting the grammaticalization path proposed in this section.
} 
No nasal prefix with semantics comparable to Japhug nu- has been described in any other Sino-Tibetan language. Hence, it is likely that it is one of the many common innovations of the Rgyalrongic languages. ${ }^{10}$

This raises the question of the source of the prefix nu- and its historical relationships to phonetically similar prefixes in Japhug. While the ultimate origin of the autobenefactive nu- is not yet clearly established, we show that it is likely to be related to two other derivations: the vertitive ${ }^{11}$ and the anticausative.

\subsection{Vertitive}

There are three derivational verbal prefixes homophonous with the spontaneous-autobenefactive (Jacques 2013a): the applicative nu- / nur-, the denominal nu- and the vertitive num-. The first two are unlikely to be historically related to the autobenefactive. In particular, while other voice derivations, including the antipassive $r \boldsymbol{r}$-and the applicative $n u$ - have been shown to originate from denominal derivations (see Jacques 2014b), the autobenefactive nu- and the denominal derivations in nu- are semantically too different for such a hypothesis to be possible: there are no denominal verbs in nu- in Japhug with an intrinsic spontaneous or autobenefactive meaning. Therefore, this section only focuses on the vertitive.

The vertitive nu- is exclusively attested with a restricted set of motion verbs, indicated in Table 2. It implies a motion back to the origin point.

Table 2: The vertitive prefix nu- in Japhug

\begin{tabular}{|c|c|c|c|}
\hline Base verb & Meaning & Derived verb & Meaning \\
\hline Ge & go & пшие & go back (home) \\
\hline$\gamma^{i}$ & come & nuyri & come back (home) \\
\hline tsum & take away & nutsum & take back (home) \\
\hline yut & bring & nuгушт & bring back (home) \\
\hline no & chase (cattle) & пuno & chase back (home) \\
\hline zyut & arrive & nuzууит & arrive back (home) \\
\hline
\end{tabular}

Vertitive verbs can be combined with the spontaneous-autobenefactive, as in example 37.

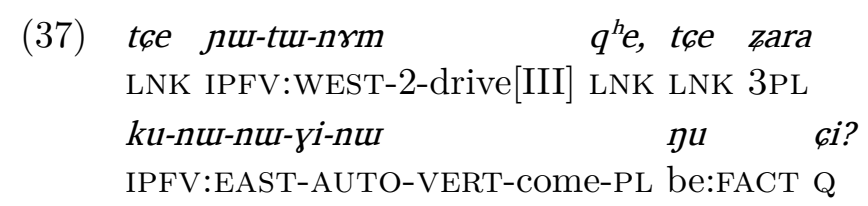

\footnotetext{
${ }^{10}$ However, one cannot completely exclude the possibility that cognate prefixes have been lost without traces in some languages.

${ }^{11}$ This term is adopted from Siouan linguistics, cf Taylor (1976).
} 
Do you drive them (the cows) over there, and then they come back by themselves? (Conversation 2003, 19)

All vertitive verbs are homophonous with the corresponding spontaneous-autobenefactive forms. Example 38 shows the use of the vertitive form of tsum 'take away', while 39 illustrates its spontaneous form. It is clear in the case of 39 that -nu-tsum cannot be interpreted as 'take back' (since a river flows in one direction and does not take back floating objects to its source); here nu-indicates that the water took away the object against the will of the speaker - it is also present with the previous verb $\beta d e$ 'throw' to express the meaning 'throw by mistake'.

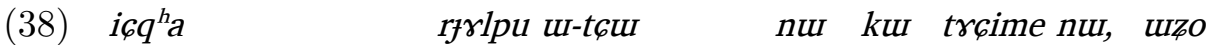
the.aforementioned king 3SG.POSS-son DEM ERG girl DEM 3SG us-rfrlk $\gamma \beta \beta \quad$ nut tqu jo-nu-tsum $q^{h} e$ 3SG.POSS-kingdom DEM LOC IFR-VERT-take.away LNK

The prince took the girl back (vertitive) to his kingdom. (140504 baixue gongzhu, 232)

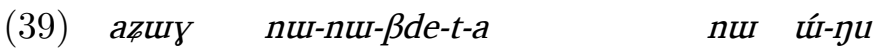

1SG:GEN PFV-AUTO-throw-PST-1SG DEM Q-be:FACT

tur-ci ku $t^{h} u$-a-nu-tsum nut úr-pu

INDEF.POSS-water ERG PFV-3 $\rightarrow$ 3'-AUTO-take.away DEM Q-be:FACT

Is it the one that I lost? Is it the one that the water took away (spontaneous)? (140427 bianfu jingji he shuiniao, 29)

There is no evidence of vertitive prefix in Khroskyabs, and it is thus probably a Rgyalrong-proper extension of the autobenefactive prefix.

It is conceivable that the vertitive meaning developped out of the autobenefactive 'take for oneself' $\rightarrow$ 'take to one's home' $\rightarrow$ 'take back home'. More precise data on the use of the autobenefactive in all Rgyalrongic languages is however necessary to confirm this hypothesis.

\subsection{Anticausative}

Japhug is one of the few languages with a specifically anticausative derivation, distinct from the passive, the reflexive and other middle markers (Jacques 2012c). This derivation turns a transitive verb into an intransitive one. The $\mathrm{S}$ of the intransitive verb corresponds to the $\mathrm{P}$ of the base verb. The anticausative is in direct concurrence with the agentless passive prefix $a-$. The semantic different between the two is that in the former, the agent is completely deleted semantically, while in the latter it is still recoverable.

The anticausative in Japhug is not marked by a prefix, but by a morphophonological alternation: the prenasalization of the onset of the verb stem (it only applies to monosyllabic verbs). 
The anticausative in Japhug is only marginally productive: it only applied to one single Tibetan loanword $\chi$ trr 'scatter' (Tibetan gtor), whose

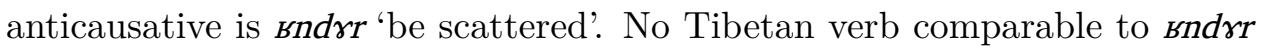
'be scattered' exists, and in any case the phonotactics of the onset of this verb itself (fricative+prenasalized voiced stop) is incompatible with that of any Tibetan language. Hence, this verb can only have been created within Japhug from its transitive counterpart $\chi$ trr 'scatter' which is a borrowing.

This example is of considerable importance, as it proves that the directionality of derivation is from the transitive verb to the intransitive one, and not the other way round. ${ }^{12}$

All known examples of anticausative alternations in Japhug are presented in Table 3.

Table 3: Examples of anticausative in Japhug

\begin{tabular}{|c|c|c|c|}
\hline basic verb & & derived verb & \\
\hline$f t s i$ & to melt (vt) & $n d z i$ & to melt (vi) \\
\hline kio & to cause to drop & ngio & to slip \\
\hline kra & to cause to fall & ngra & to fall \\
\hline plut & to destroy & mblut & to be destroyed \\
\hline prrt & to cut & $m b r r t$ & to be cut \\
\hline руав & to turn over (vt) & mbуав & to turn over (vi) \\
\hline$q r t$ & to separate & $N G r t$ & to be separated \\
\hline$q^{h}$ ruut & to completely scratch & NGrut & to be completely scratched \\
\hline qru & to cut, to tear, to break & NGruI & to break (vi), be torn \\
\hline $\operatorname{tgr} \beta$ & to burn (vt) & $n d_{z \gamma} \beta$ & to be burned \\
\hline$t^{h} u$ & $\begin{array}{l}\text { to pitch (tent), } \\
\text { to build (road, bridge) }\end{array}$ & ndu & $\begin{array}{l}\text { to appear (rainbow), } \\
\text { to be built (road, bridge) }\end{array}$ \\
\hline$\chi t r r$ & to spill & sndrr & to be spilled \\
\hline $\operatorname{tsa} \beta$ & to cause to roll & $n d z a \beta$ & to roll (vi) \\
\hline qras & to tear & NGrab & to be torn \\
\hline qia & to tear & NGia & to get loose \\
\hline qlut & to break & NGlut & to be broken \\
\hline$s \gamma p^{h} \gamma r$ & to shake off, to wipe off & $m b r r$ & wiped off \\
\hline pri & to tear & $m b r i$ & to be torn \\
\hline$x t^{h}$ om & to put horizontally & ndom & to be horizontal \\
\hline tөуав & to squeeze out & ndzуав & to be squeezed out \\
\hline$k \gamma \gamma$ & to bend & ggry & to be bent \\
\hline$q r r z$ & to shave & NGrrZ & to break (of hair, dry leaves etc) \\
\hline$c^{h} \gamma \beta$ & to flatten, to crush & $\operatorname{nfr} \beta$ & to be crushed, flattened \\
\hline cuI & to open & лғиш & to be opened \\
\hline$p^{h} a b$ & to split & $m b a b$ & to split, break \\
\hline
\end{tabular}

The anticausative radically differs from autobenefactive in several

\footnotetext{
${ }^{12}$ In addition, we observe that several phonological contrasts found in the transitive verbs, such as aspiration, are neutralized in the corresponding anticausative verbs, a fact that strengthens the idea that the intransitive verbs are derived from the transitive ones in this voice alternation.
} 
ways. First, it is an intransitivizing derivation, while the autobenefactivespontaneous does not modify the verb valency. Second, the two derivations are formally different (prefix vs prenasalization).

Yet, there is some degree of semantic overlap between the two derivations: both can be used to express spontaneous events occurring without any external agent. Moreover, while they are phonetically different, it is conceivable that onset prenasalisation is the regular phonetic development of nasal prefixes before stops and affricates, while the tautosyllabic nu- represents a regularized allomorph occurring before onsets that cannot undergo prenasalization and later generalized everywhere. Hence, it is possible that these two derivations came from a common origin: a nasal prefix expressing spontaneous / non-volitive actions.

The anticausative is widespread throughout the Sino-Tibetan family, even in Chinese (Sagart \& Baxter 2012) and Tibetan (Jacques 2012b), and can safely be reconstructed to the proto-language. ${ }^{13}$ The question is whether the primary meaning of this derivation was spontaneous action or specifically anticausative (with loss of transitivity); this can only be effectively tested in Sino-Tibetan languages that have morphological transitivity.

In Kiranti languages, which like Rgyalrongic languages, have distinct transitive and intransitive conjugations, example of voicing alternations are relatively few (in Khaling for instance, only eight examples are attested, see Jacques 2013b). The voiced counterpart of such verb pairs is nearly always intransitive, with a clear anticausative meaning identical the Japhug examples in Table 3.

Yet, there is at least one example of voicing alternation where the voiced remains morphologically transitive: Khaling plum- 'rinse in water' vs blum'sink in water' are both transitive; the voiced form blum- is conjugated intransitively, and takes an agent marked with the ergative (the liquid in which one sinks), as in 40 .

\section{(40) $\quad k u-2 \varepsilon \quad$ 2i-blum-sts}

water-ERG INV/2-sink-1SG:S/O:PST

I sank in the water.

Such an example may suggest that the primary function of the anticausative was that of spontaneous action, and not intransitivization. In this view, Japhug and other Rgyalrongic languages have reshaped the original

\footnotetext{
${ }^{13}$ Although some authors appear to confuse the anticausative and causative $s$-derivations (Mei 2012), the general consensus is that these are completely distinct phenomena (LaPolla 2003, Hill 2014): languages as diverse as Japhug, Tibetan, Rawang and Jingpo have both distinct causative (marked by a coronal fricative prefix) and anticausative (marker by voicing alternation) derivations. This fact is difficult to reconcile with the idea that voicing alternations are due to the devoicing of voiced initials caused by the prefix ${ }^{*} s$.
} 
spontaneous derivation into two distinct morphological processes with specialized semantics, which most Sino-Tibetan languages have only preserved the spontaneous derivation in its more reduced anticausative function.

If this hypothesis is correct, more examples such as Khaling plum-vs blum-, with voicing alternation without intransitivation, should be discovered in morphologically rich languages of the family.

\section{Conclusion}

The spontaneous-autobenefactive prefix nul- in Japhug has cognates in most Rgyalrongic languages. Further reasearch will be needed to determine to what extent the use of the cognate prefixes in the other languages are similar or different from that of Japhug nu-. In particular, it is unclear whether the permansive value of nu- is restricted to Japhug or found elsewhere, and whether the cognate prefixes have the same values in the imperative.

Additional research on the historical origin of the spontaneousautobenefactive will also require data from other languages. Within Rgyalrongic, it is especially important to collect all examples of irregular spontaneous-autobenefactive forms, such as Japhug $\mathrm{y}^{\gamma}<$ nuI $>\boldsymbol{\zeta u}$ $<$ AUTO > exist:SENS. Outside of Rgyalrongic, progress may be achieved by looking for traces of cognate spontaneous markers. In particular, it could be fruitful to search for cases of voiced / unvoiced verb pairs in which both verbs are morphologically transitive, like Khaling |plum-| 'rinse' and |blum-| 'sink'.

Finally, the data presented in this paper is of interest to typologists working on middle marking systems, as Japhug is one of the few languages with specific markers to express reflexive, passive, reciprocal, antipassive, anticausative and autobenefactive derivations, in other words, a language in which all subsections of the middle domain are clearly kept separate by distinct morphology.

\section{References}

Bickel, Balthasar, Manoj Rai, Netra Paudyal, Goma Banjade, Toya Nath Bhatta, Martin Gaenszle, Elena Lieven, Iccha Purna Rai, Novel K Rai \& Sabine Stoll. 2010. The syntax of three-argument verbs in Chintang and Belhare (Southeastern Kiranti). In Andrej Malchukov, Martin Haspelmath \& Bernard. Comrie (eds.), Bernard. Studies in ditransitive constructions: a comparative handbook, 382-408. Berlin, New York: Mouton de Gruyter.

DeLancey, Scott. 1981. The category of direction in Tibeto-Burman. Linguistics of the Tibeto-Burman Area 6.1. 83-101. 
van Driem, George. 1993. A Grammar of Dumi. Berlin: Mouton de Gruyter.

François, Alexandre. 2003. La sémantique du prédicat en mwotlap (Vanuatu). Louvain: Peeters.

Gong, Xun. 2014. Personal agreement system of Zbu rGyalrong (Ngyaltsu variety). Transactions of the Philological Society 112.1. 44-60.

Hill, Nathan W. 2014. A note on voicing alternation in the Tibetan verbal system. Transactions of the Philological Society 112.1. 1-4.

Jacques, Guillaume. 2010a. The inverse in Japhug Rgyalrong. Language and Linguistics 11.1. 127-157.

Jacques, Guillaume. 2010b. The origin of the reflexive prefix in Rgyalrong languages. Bulletin of the School of Oriental and African studies 73.2. 261-268.

Jacques, Guillaume. 2012a. Agreement morphology: the case of Rgyalrongic and Kiranti. Language and Linguistics 13.1. 83-116.

Jacques, Guillaume. 2012b. An Internal Reconstruction of Tibetan Stem Alternations. Transactions of the Philological Society 110.2. 212-224.

Jacques, Guillaume. 2012c. Argument demotion in Japhug Rgyalrong. In Katharina Haude \& Gilles Authier (eds.), Ergativity, Valency and Voice, 199-226. Berlin: Mouton De Gruyter.

Jacques, Guillaume. 2012d. From denominal derivation to incorporation. Lingua 122.11. 1207-1231.

Jacques, Guillaume. 2013a. Applicative and tropative derivations in Japhug Rgyalrong. Linguistics of the Tibeto-Burman Area 36.2. 1-13.

Jacques, Guillaume. 2013b. Derivational morphology in Khaling. In Li Fang-Kuei Society for Chinese Linguistics, Young Scholar Symposium, University of Washington at Seattle.

Jacques, Guillaume. 2013c. Harmonization and disharmonization of affix ordering and basic word order. Linguistic Typology 17.2. 187-217.

Jacques, Guillaume. 2014a. Clause linking in Japhug Rgyalrong. Linguistics of the Tibeto-Burman Area 37.2. 263-327.

Jacques, Guillaume. 2014b. Denominal affixes as sources of antipassive markers in Japhug Rgyalrong. Lingua 138. 1-22.

Jacques, Guillaume. to appear. Generic person marking in Japhug and other Rgyalrong languages. In Joana Jansen \& Spike Gildea (eds.), Diachrony of hierarchical systems, Amsterdam: John Benjamins. 
Jacques, Guillaume \& Anton Antonov. 2014. Direct / inverse systems. Language and Linguistics Compass 8/7. 301-318.

Kemmer, Suzanne. 1993. The Middle Voice. Amsterdam: Benjamins.

Lai, Yunfan. 2013. La morphologie affixale du lavrung wobzi. Université Paris III MA thesis.

LaPolla, Randy. 2003. An overview of Sino-Tibetan morphosyntax. In Graham Thurgood \& Randy J. LaPolla (eds.), The Sino-Tibetan Languages, 22-42. London \& New York: Routledge.

LaPolla, Randy \& Jiangling Yang. 2005. Reflexive and middle marking in Dulong/Rawang. Himalayan Linguistics 2. 1-13.

Mei, Tsulin. 2012. The causative ${ }^{*_{\text {s- }}}$ and nominalizing ${ }^{*}$-s in Old Chinese and related matters in Proto-Sino-Tibetan. Language and Linguistics 13.1. $1-28$.

Michailovsky, Boyd. 1988. La langue hayu. Paris : Editions du CNRS.

Michailovsky, Boyd, Martine Mazaudon, Alexis Michaud, Séverine Guillaume, Alexandre François \& Evangelia Adamou. 2014. Documenting and researching endangered languages: the Pangloss Collection. Language Documentation and Conservation 8. 119-135.

Opgenort, Jean-Robert. 2004. A Grammar of Wambule. Leiden: Brill.

Pooth, Roland. 2014. Die Diathesen Aktiv vs. Medium und die Verbsemantik im Vedischen der Rgveda-Samhita: Leiden University dissertation.

Sagart, Laurent \& William H. Baxter. 2012. Reconstructing the s- prefix in Old Chinese. Language and Linguistics 13.1. 29-59.

Sun, Jackson T.-S. 2000. Stem Alternations in Puxi Verb Inflection: Toward Validating the rGyalrongic Subgroup in Qiangic. Language and Linguistics 1.2. 211-232.

Sun, Jackson T.-S. 2007. The irrealis category in rGyalrong. Language $\mathscr{E}$ Linguistics 8.3. 797-819.

Sun, Jackson T.-S. 2014. Sino-Tibetan: Rgyalrong. In Rochelle Lieber \& Pavol Stekauer (eds.), The Oxford Handbook of Derivational Morphology, 630-650. Oxford: Oxford University Press.

Sun, Jackson T.-S. \& Shidanluo. $2002 . \quad$ Caodeng Jiarongyu yu rentong dengdi xiangguan de yufa xianxiang 草登嘉戎語與「認同等第」相關的語法現象 (Empathy Hierarchy in Caodeng rGyalrong grammar). Language and Linguistics 3.1. 79-99. 
Taylor, Allan R. 1976. On Verbs of Motion in Siouan Languages. International Journal of American Linguistics, 42.2. 287-296.

Zúñiga, Fernando \& Seppo Kittilä. 2010. Benefactives and Malefactives: Typological Perspectives and Case Studies. Amsterdam: Benjamin. 